\title{
Performance of elite banana (Musa acuminata, AAA) cultivars in four locations of Puerto Rico',
}

\author{
Héber Irizarry, Edmundo Rivera, Isabel Beauchamp de Caloni \\ and Rubén Guadalupes
}

\begin{abstract}
Dwarf banana cultivars were evaluated for yield and fruit quality under different ecological conditions over a 3-year period. Under semi-arid conditions at Santa Isabel (south coast) with drip irrigation, cultivars Ziv and Grand Nain averaged $60,465 \mathrm{~kg} / \mathrm{ha} /$ year of marketable fruits, equivalent to 3,322 boxes. At Yabucoa, with high rainfall and no irrigation, cultivars Valéry and Grand Nain averaged $50,765 \mathrm{~kg} / \mathrm{ha} /$ year, or 2,789 boxes. The removal of two or more lower hands soon after bunch shooting significantly reduced yields in all cultivars but increased fruit size and weight in the distal hand. Taste panel evaluations of appearance, flavor, texture and overall acceptability classified ethylene-ripened fruits of Grand Nain, Valéry and Johnson as "acceptable" for the fresh-fruit markef. When properly ripened, none of the cultivars were affected by "finger drops."
\end{abstract}

\section{RESUMEN}

Comportamiento de cultivares de guineo (Musa acuminata, AAA) en cuatro localidades de Puerto Rico

Se determinó el potencial de producción y la calidad de los guineos cultivados en diferentes suelos y condiciones climatológicas durante 3 años sucesivos. Los experimentos se llevaron a cabo en Santa Isabel (costa sur) con riego por goteo y en Yabucoa (costa este), Corozal y Gurabo (interior) sin riego.

En la cosecha de plantilla se obtuvo el peso vendible y no vendible por cultivar, luego se utilizó este dato para determinar el rendimiento neto por hectárea en todas las cosechas. En el experimento de Yabucoa se evaluó el efecto de la práctica de cortar las manos inferiores sobre el tamaño y peso medio de las frułas en la mano distal del racimo. Además, se hicieron pruebas para determinar la aceptabilidad de las frutas maduras por un grupo de catadores.

En Santa Isabel, con riego por goteo, la producción media de las cultivares Ziv y Grand Nain fue de $60,465 \mathrm{~kg}$./ha./año de frutas vendibles, equivalente a 3,322 cajas. Los rendimientos mayores sin riego se obtuvieron en el experimento de Yabucoa, donde las cultivares Valéry y

'Manuscript submitted to Editorial Board 17 January 1989.

${ }^{2}$ This paper covers work carried out cooperatively between the Agricultural Research Service-USDA and the Agricultural Experiment Station, University of Puerto Rico, Río Piedras, P. R.

"Research Horticulturist and Agronomist, respectively, Agricultural Research ServiceUSDA; Food Technologist and Horticulturist, respectively, Agricultural Experiment Station, University of Puerto Rico, Río Piedras, P. R. 
Grand Nain produjeron una media de $50,765 \mathrm{~kg}$./ha./año de frutas ó 2,789 cajas. En la Subestación de Gurabo se obtuvieron los rendimientos más bajos de todas las cultivares.

La remoción de dos o más manos inferiores del racimo inmaturo redujo significativamente los rendimientos en todas las cultivares, pero reflejó un aumento en el tamaño y el peso medio de las frutas en la mano distal del racimo.

En $50 \%$ de las pruebas los cafadores no detectaron diferencias apreciables entre las cultivares para apariencia, sabor, textura y aceptabilidad general de las frutas maduras, clasificándolas como aceptables para el mercado. En las restantes pruebas se detectaron diferencias significativas en la cultivar Ziv debido a puntuaciones bajas mayormente causados por la pobre aparienca en el color de la fruta y la presencia de sabores extraños. Sin embargo, los catadores se mantuvieron indecisos con relación a su preferencia por estas frutas.

Después de la maduración no se observó ningún "desprendimiento prematuro" de las frutas.

\section{INTRODUCTION}

Puerto Rico does not export or import bananas. Annual production is estimated at 90,900 metric tons, about $15 \%$ of which is consumed as fresh ripe fruit. Most of the production is from old or so-called "land varieties" traditionally grown in the mountain region and intercropped with coffee without proper management. Under these conditions, production is low and of poor quality.

In the early 1930's, González-Ríos (3), surveyed the mountain region and reported that ten clones were grown intermingled with coffee. During the 1940's, Osuna (7) identified Giant, Dwarf Montecristos and Guarán as the leading varieties, all intercropped with shaded coffee.

In the 1960's, Sánchez-Nieva and collaborators $(10,11,12)$ evaluated Giant Montecristo banana produced in monoculture plantings at the AESUPR Fortuna and Adjuntas Substations. Eighty-five percent of the bunches produced at Fortuna, with supplemental irrigation, averaged 17 $\mathrm{kg}$. Those from the humid uplands at Adjuntas were heavier, averaging $24 \mathrm{~kg}$ per bunch. In addition, the authors attributed to cropping site location certain differences in flowering pattern, length of crop cycle, and fruit-ripening characteristics.

Recently, Pool (8) reported yields of 48.4 t/ha of marketable fruits from the plant crop of Grand Nain cultivar produced with drip irrigation on the semi-arid south coast.

In Puerto Rico climate, soils, and the infrastructure make feasible a modern banana industry for local needs and export markets (4). This, however, must be accomplished with a modern technological base.

High-quality bananas command higher prices because size of the fruit and appearance are the principal criteria in grading. Boncanto (1), investigating the effect of early removal of lower hands on fruit characteristics, reported that mature green bunches with fewest hands produced the heaviest, longest and thickest fruits. Calvo and Soto (2) concluded 
that the removal of lower hands from the immature bunch is a justifiable practice to improve final fruit quality in bananas.

This study reports on the yield and quality of elite dwarf banana cultivars grown under correct management in four agricultural zones for three successive years.

\section{MATERIALS AND METHODS}

Four field experiments were performed from December 1981 through July 1985 at the AES-UPR Corozal and Gurabo Substations, and on private farms in the municipalities of Yabucoa and Santa Isabel. The cultivars evaluated were Grand Nain, Valéry, Ziv and Johnson. Both Grand Nain and Valéry are highly adaptive, and are well-known internationally. Ziv was recently introduced from Israel. Johnson is an apparent dwarf clone selected locally from Giant Montecristo.

All cultivars were arranged in a randomized complete block design with 6 replications of 9 plants per plot.

\section{Corozal Site}

The Corozal Substation is located in the humid north-central uplands, at an elevation of about $200 \mathrm{~m}$. During the course of the experiment mean annual rainfall was $1,800 \mathrm{~mm}$ with pan evaporation $1,400 \mathrm{~mm}$. Average monthly minimum and maximum temperatures were 19.7 and $30.2^{\circ} \mathrm{C}$, respectively. The soil is a Corozal clay, pH 5.3.

\section{Gurabo Site}

The Gurabo Substation is located in the humid east-central interior valleys, at an elevation of about $80 \mathrm{~m}$. Throughout the experiment the mean annual rainfall was $1,650 \mathrm{~mm}$ and pan evaporation was $1,620 \mathrm{~mm}$. Average monthly minimum and maximum temperatures were 19.2 and $30.5^{\circ} \mathrm{C}$, respectively. The soil is a Coloso clay, $\mathrm{pH} 6.5$.

\section{Yabucoa Site}

The Yabucoa experiment was located at about sea level. Throughout the experiment mean annual rainfall was $2,115 \mathrm{~mm}$, and pan evaporation was $1,650 \mathrm{~mm}$. Average monthly minimum and maximum temperatures were 21.3 and $30.3^{\circ} \mathrm{C}$, respectively. The soil is a Talante sandy clay loam, $\mathrm{pH} 4.6$.

\section{Santa Isabel Site}

The Santa Isabel experiment was located at an elevation of $50 \mathrm{~m}$. Throughout the experiment mean annual rainfall was $1,000 \mathrm{~mm}$ and pan evaporation was $1930 \mathrm{~mm}$. Average monthly minimum and maximum temperatures were 21.0 and $31.2^{\circ} \mathrm{C}$, respectively. The soil is a Jacaguas silty clay loam, with soil $\mathrm{pH} 7.8$.

At all experimental sites the soil was plowed to about $25 \mathrm{~cm}$ depth. It was harrowed twice. 
Medium size banana suckers, weighing 1.8 to $2.3 \mathrm{~kg}$, were planted in rows spaced at 1.8 by $1.8 \mathrm{~m}$ with alleys 3.1 to $3.7 \mathrm{~m}$ every two rows, about 2,000 plants at Santa Isabel, and 2.250 plants/ha in the other experiments.

The Corozal, Gurabo and Yabucoa experiments received in the plant crop 3,000 kg/ha of a 10-5-20-3 $\left(\mathrm{P}_{2} \mathrm{O}_{5}, \mathrm{~K}_{2} \mathrm{O}, \mathrm{MgO}\right)$ fertilizer supplemented with a minor element mixture at the rate of $25.4 \mathrm{~kg} / \mathrm{Tm}$ of fertilizer. the fertilizer was applied at the rate of $500,750,1,000$ and $750 \mathrm{~kg} / \mathrm{ha}$ at 2, 5 , 8 and 11 months after planting, respectively. Thereafter, the ratoons were fertilized at the rate of $750 \mathrm{~kg} / \mathrm{ha}$ every 3 months.

A drip irrigation system was provided for the Santa Isabel experiment. The plants were fertilized weekly via the irrigation water with 6 $\mathrm{kg} / \mathrm{ha}$ of $\mathrm{N}$ and $15 \mathrm{~kg} / \mathrm{ha}$ of $\mathrm{K}_{2} \mathrm{O}$. Fertilization began 6 weeks after planting. Plants were drip irrigated every other day. Each plant received approximately 135 to 160 liters/week. Occasionally, during the wet months of September to November, the irrigation scheme was modified according to the amount of rainfall recorded.

Nematodes and corm weevil (Cosmopolites sordidus) were controlled with Aldicarb (Temik $10-\mathrm{G})^{4}$ at the rate of $28 \mathrm{~g} / \mathrm{plant}$ administered at planting and at 4-month intervals thereafter.

Weed control was by postemergence applications of glyphosate (Round-up), at the rate of 1.5\%. A "desuckering" program was implemented 4 to 6 months after planting. This program maintained as a contiguous unit, the mother plant plus two suckers, the latter representing "daughter" and "grand-daughter" plants.

At Corozal, Gurabo and Yabucoa plants were sprayed for control of Yellow Sigatoka (Mycosphaerella musicola), in accordance with published (5) recommendations. Sigatoka control was not necessary at Santa Isabel.

In all experiments, the lowest hand and the male flower bud were removed from the bunches immediately after all hands were visible. In addition, hand-removal sub-treatments were evaluated at Yabucoa. These consisted of pruning either the lowest (false) hand with the male flower bud, or the second, or the third lower hands. In addition, the bunches were covered with opaque polyethylene bags.

At all locations the bunches were harvested when the fruits were $3 / 4$ full. After obtaining the gross weight, we dissected the bunches into hands and rachis to determine marketable and non-marketable weights. Nonmarketable weight included the combined weight of the bunch rachis

\footnotetext{
Trade names in this publication are used only to provide specific information. Mention of a trade name does not constitute a warranty of equipment of materials by the Agricultural Experiment Station of the University of Puerto Rico, nor is this mention a statement of preference over other equipment or materials.
} 
and one or more lower hands if their fruits were undersized, sharply curved or deformed. Other defects requiring rejection were ripened, sunburned or mutilated fruits. These data were further used to calculate the percentages of nonmarketable weights in the ratoon-crop bunches.

In the Yabucoa planting, middle fruits from the distal hand were sampled to determine fruit mean weight, outer length and diameter.

Fruits from Santa Isabel and Gurabo were field-packed into $18.2 \mathrm{~kg}$ cardboard boxes and sent to the AES Food Technology Laboratory, at Río Piedras. They were ripened in ethylene gas in accordance with Sánchez-Nieva et al. (9). When the ripened bananas reached grade color 6 a trained taste panel evaluated them for appearance, flavor, texture (mouthfeel) and overall acceptability. The panelists used the Larmond 6 -point scale (6).

\section{RESULTS AND DISCUSSION}

At all locations, the lowest and highest percentages of nonmarketable weight occurred in Valéry and Grand Nain cultivars, respectively (table 1). Among locations, the lowest rejection for all cultivars was $7.3 \%$ at Santa Isabel under drip irrigation, and $8.4 \%$ at Yabucoa, the latter without irrigation, but receiving abundant rainfall. The highest percentage of nonmarketable weight was recorded at Gurabo, averaging $17.6 \%$ for all cultivars.

The highest marketable yields were recorded at Santa Isabel (table 2). All cultivars yielded well, averaging $173,069 \mathrm{~kg} / \mathrm{ha}$ (9,510 boxes) of marketable fruits from the combined harvests of plant and ratoon crops. Among cultivars, Ziv and Grand Nain were the most productive, averaging $60,465 \mathrm{~kg} / \mathrm{ha} / \mathrm{year}$. This is equivalent to 3,322 boxes of marketable fruits. These are exceptional yields and were made possible by a combination of factors: a higher percentage of plants producing marketable bunches, a shorter crop cycle, a significant increase of bunch weight in ratoon plants, and a lower percentage of fruit rejects.

In the plant crop some $99 \%$ of the plants produced a marketable bunch in 11 months (table 2). During the final 25 months the ratoon

TABLE 1.-Nonmarketable weight determined during the plant crop harvest of banana cultivars grown at four locations in Puerto Rico

\begin{tabular}{|c|c|c|c|c|c|}
\hline Cultivar & Santa Isabel ${ }^{1}$ & Yabucoa & Corozal & Gurabo & Average \\
\hline Valéry & 6.9 & 7.8 & 14.9 & 16.7 & 11.6 \\
\hline Ziv & 7.4 & - & - & 17.8 & 12.6 \\
\hline Johnson & 7.4 & 8.6 & 15.7 & 17.5 & 12.3 \\
\hline Grand Nain & 7.6 & 8.7 & 16.9 & 18.3 & 12.9 \\
\hline Average & 7.3 & 8.4 & 15.8 & 17.6 & \\
\hline
\end{tabular}

'Planted with drip irrigation. 
TABLE 2.-Marictable yields obtained from four banana cultivars grown with drip irrigation during a s-year period at the Santa Isabel,

\begin{tabular}{|c|c|c|c|c|c|c|c|c|c|c|}
\hline \multirow[b]{2}{*}{ Cultivar } & \multicolumn{3}{|c|}{ Plant-crop } & \multicolumn{3}{|c|}{ Ratoon-crops } & \multicolumn{2}{|c|}{ Total production } & \multicolumn{2}{|c|}{ Average production } \\
\hline & $\begin{array}{l}\text { Weight/ } \\
\text { bunch }\end{array}$ & $\begin{array}{c}\text { Yield/ } \\
\text { ba }\end{array}$ & $\begin{array}{c}\text { Plants } \\
\text { harvested }\end{array}$ & $\begin{array}{l}\text { Weight/ } \\
\text { bunch }\end{array}$ & $\begin{array}{c}\text { Yield/ } \\
\text { ha }\end{array}$ & $\begin{array}{c}\text { Bunches } \\
\text { harvested } \\
\text { stump }\end{array}$ & $\begin{array}{c}\text { Yield/ } \\
\text { ha }\end{array}$ & $\begin{array}{l}\text { Boxes' of } \\
\text { fruits/hat }\end{array}$ & $\begin{array}{c}\text { Yield/hal } \\
\text { year }\end{array}$ & $\begin{array}{c}\text { Boxes of } \\
\text { fruitsfnal } \\
\text { year }\end{array}$ \\
\hline & $\mathrm{kg}_{0}$ & $\stackrel{k g}{h g}$ & $\%$ & $\mathrm{~kg}$ & $\mathrm{~kg}^{\circ}$ & No. & $\begin{array}{c}\mathrm{kg} \\
185\end{array}$ & No. & $\stackrel{\mathrm{kg}}{9}$ & No. \\
\hline Grand Nain & $\begin{array}{l}25.4^{\mathrm{an}} \\
24.0^{\mathrm{nb}}\end{array}$ & $\begin{array}{l}50,577.2^{u} \\
47,676.2^{\mathrm{ub}}\end{array}$ & $\begin{array}{l}99.0 \\
99.3\end{array}$ & $28.8^{\mathrm{nb}}$ & $129,258.8^{\mathrm{ab}}$ & $\begin{array}{l}2.5 \\
2.3\end{array}$ & $176,936.0^{\mathrm{a}}$ & 9,722 & $58,978.7$ & 3,241 \\
\hline Valéry & $22.4^{b}$ & $44,551.0^{6}$ & 99.4 & $28.1^{\mathrm{ib}}$ & $125,199.0^{\mathrm{nb}}$ & 2.2 & $169,750.0^{b}$ & 9,327 & $56,583.3$ & 3,109 \\
\hline Johnson & $23.2^{\mathrm{b}}$ & $46,162.8^{b}$ & 99.5 & $27.1^{b}$ & $113,576.0^{b}$ & 2.1 & $159,738.8^{\mathrm{b}}$ & 8,777 & $53,246,3$ & 2,926 \\
\hline
\end{tabular}

One box of bananas weighs $18.2 \mathrm{~kg}$.

Means followed by the same letters do not differ significantly at $\mathrm{P}=0.05$ probability level. 
TABLE 3.-Marketable yields obtained from three banana cultivars grown with drip inrigation during a s-year period at Yabucoa, Puerto Rico.

\begin{tabular}{|c|c|c|c|c|c|c|c|c|c|c|}
\hline \multirow[b]{2}{*}{ Cultivar } & \multicolumn{3}{|c|}{ Plant-crop } & \multicolumn{3}{|c|}{ Ratoon-crops } & \multicolumn{2}{|c|}{ Total production } & \multicolumn{2}{|c|}{ Average production } \\
\hline & $\begin{array}{l}\text { Weight/ } \\
\text { bunch }\end{array}$ & $\begin{array}{c}\text { Yield } \\
\text { ha }\end{array}$ & $\begin{array}{c}\text { Plunts } \\
\text { harvested }\end{array}$ & $\begin{array}{l}\text { Weight } \\
\text { bunch }\end{array}$ & $\begin{array}{c}\text { Yield } \\
\text { ha }\end{array}$ & $\begin{array}{l}\text { Bunches } \\
\text { harvested/ } \\
\text { stump }\end{array}$ & $\begin{array}{c}\text { Yield } \\
\text { ha }\end{array}$ & $\begin{array}{l}\text { Boxes of } \\
\text { fruits/ha }\end{array}$ & $\begin{array}{c}\text { Yieldhal } \\
\text { year }\end{array}$ & $\begin{array}{c}\text { Boxes of } \\
\text { fruits/ha/ } \\
\text { year }\end{array}$ \\
\hline Valéry & $\begin{array}{c}k g \\
19.6^{\mathrm{bs}}\end{array}$ & $\frac{\mathrm{kg}}{43,605.6^{\mathrm{b}}}$ & $\begin{array}{c}\% \\
98.9\end{array}$ & $\begin{array}{c}\mathrm{kg} \\
22.4^{\mathrm{a}}\end{array}$ & $\begin{array}{c}\mathrm{kg} \\
110,806.6^{2}\end{array}$ & $\begin{array}{l}\text { No. } \\
2.2\end{array}$ & $\underset{154,412.2^{2}}{\mathrm{~kg}}$ & $\begin{array}{l}\text { No. } \\
8,484\end{array}$ & $\begin{array}{c}\mathrm{kg} \\
51,471\end{array}$ & $\begin{array}{l}\text { No. } \\
2,828\end{array}$ \\
\hline Grand Nain & $25.1^{\mathrm{B}}$ & $55,872.2^{n}$ & 98.9 & $22.8^{\mathrm{a}}$ & $94,305.0^{\mathrm{a}}$ & 1.8 & $150,177 \cdot 2^{\mathrm{ab}}$ & 8,251 & 50,059 & 2,750 \\
\hline Johnson & $20.6^{b}$ & $46,150.0^{b}$ & 99.6 & $21.4^{\mathrm{a}}$ & $96,500.5^{n}$ & 2.0 & $142,650.5^{b}$ & 7,837 & 47,550 & 2,612 \\
\hline
\end{tabular}

One box of bananas weighs $18.2 \mathrm{~kg}$.

2Means followed by the same letters do not differ significantly at $P=0.05$ probability level. 
plants produced heavier bunches and averaged 2.2 bunches/stump, thus representing $20 \%$ increase over the plant crop.

Throughout the Santa Isabel study, heavier bunches were produced by cultivar Ziv with a mean weight of $27.8 \mathrm{~kg}$ (table 2 ). This weight was not significantly greater than that of Grand Nain (26.4 kg).

At Yabucoa both Valéry and Grand Nain were the best yielders, averaging $152,294 \mathrm{~kg} / \mathrm{ha}$ (8,368 boxes) during the 3-year period (table 3 ). This represents an average annual production of $50,765 \mathrm{~kg} / \mathrm{ha}$, equivalent to 2,789 boxes.

The plant crop yields at Yabucoa compared favorably with those of Santa Isabel (table 2). However, in successive ratoon crops at Yabucoa, yields were moderately affected by dry periods occurring early each year. Pan evaporation values exceeded rainfall during the months of January, March and April of 1983 through 1985. Under these conditions, perhaps enhanced by the low moisture retention capacity of the Talante granitic soil, only Valéry ratoon plants increased yield. This amounted to about $15 \%$ gain over the plant crop (table 3). Grand Nain produced the heaviest individual bunches at Yabucoa, but the differences were statistically significant only in the plant crop (table 3 ).

The removal of two or more lower hands from the immature bunches reduced yields irrespective of cultivar (table 4). In the plant crop, the three-hand removal sub-treatment caused a significant reduction in weight of $1.4 \mathrm{~kg} /$ bunch equivalent to $3,655 \mathrm{~kg} / \mathrm{ha}$. In successive ratoons, yields/ha were expressively affected by the hand-removal sub-treatments. Total yields were drastically reduced in the order of 15 to $18 \%$, depending on the number of hands pruned. However, this treatment increased the size of individual fruits in the bunch's distal hand (table 4). In addition, fruit length and weight increased by 7 and $22 \%$, respectively, with the removal of three hands. Fruit diameter was the least affected parameter. It is assumed that pruning similarly influenced the weight and size of the fruits in all remaining hands of the bunch. Boncanto (1), and Calvo and Soto (2) reported that the technique improved the grading of all fruits in the bunch at the expense of reducing bunch weight and total yields.

At Corozal, on a less fertile Ultisol, the higher-yielding cultivars were Grand Nain and Johnson (table 5). Over the 3-year period, total production averaged $126,070 \mathrm{~kg} / \mathrm{ha}(6,927$ boxes) equivalent to $42,023 \mathrm{~kg} / \mathrm{ha}$ or 2,309 boxes per annum. In the Corozal plant crop, both cultivars averaged $44,620 \mathrm{~kg} / \mathrm{ha}$ (table 5). This yield compared favorably with those of Yabucoa and Santa Isabel. However, the Corozal experiment required 15 months to complete the plant-crop cycle.

Although in successive ratoon crops all cultivars averaged a $10 \%$ increase over the plant crop, total yields were low during the final 21 months, amounting only to 1.6 bunches per stump. Cultivar Grand Nain 
TABLE 4.-Effect of bunch pmining on marketable yields and fruit characteristics of bananas grown during a 3-day period at Yabucoa, Puerto Rico

\begin{tabular}{|c|c|c|c|c|c|c|c|c|c|}
\hline \multirow[b]{2}{*}{ Hands removed } & \multicolumn{2}{|c|}{ Plant-crop } & \multicolumn{2}{|c|}{ Ratoon-crops } & \multicolumn{2}{|c|}{ Total production } & \multicolumn{3}{|c|}{$\begin{array}{c}\text { Distal hand fruit measurement } \\
\text { and weight }\end{array}$} \\
\hline & $\begin{array}{l}\text { Weig'tht/ } \\
\text { bunch }\end{array}$ & $\begin{array}{l}\text { Yield/ } \\
\text { ha }\end{array}$ & $\begin{array}{l}\text { Weight/ } \\
\text { bunch }\end{array}$ & $\begin{array}{c}\text { Yield/ } \\
\text { ha }\end{array}$ & $\begin{array}{l}\text { Yield/ } \\
\text { ha }\end{array}$ & $\begin{array}{l}\text { Boxes of } \\
\text { fruits/ha }\end{array}$ & Diameter & $\begin{array}{l}\text { Outer } \\
\text { length }\end{array}$ & $\begin{array}{c}\text { Average } \\
\text { weight }\end{array}$ \\
\hline No. & $\mathrm{kg}$ & $k g$ & $\mathrm{~kg}$ & $\mathrm{~kg}$ & $k g$ & No. & $\mathrm{cm}$ & $\mathrm{cm}$ & $g$ \\
\hline One & $22.5^{\mathrm{a}_{\mathrm{i}}}$ & $50,361.1^{\mathrm{a}}$ & $22.6^{\mathrm{a}}$ & $116,974.9^{3}$ & $167,336.0^{\mathrm{a}}$ & 9,194 & $3.5^{\mathrm{a}}$ & $18.8^{\mathrm{th}}$ & $131.4^{b}$ \\
\hline Two & $21.7^{\mathrm{ab}}$ & $48,561.1 \mathrm{ab}$ & $22.7^{\mathrm{a}}$ & $95,582.1^{b}$ & $142,143.2^{\mathrm{b}}$ & 7,810 & $3.5^{2}$ & $19.6^{\mathrm{ab}}$ & $141.2^{6}$ \\
\hline Three & $21.1^{\mathrm{b}}$ & $46,705.6^{\mathrm{b}}$ & $21.3^{a}$ & $91,055.1^{b}$ & $137,760.7^{b}$ & 7,569 & $3.6^{a}$ & $20.3^{\mathrm{a}}$ & $168.9^{\mathrm{a}}$ \\
\hline
\end{tabular}

'One box of bananas weighs $18.2 \mathrm{~kg}$.

"Means followed by the same letters do not differ significantly at $\mathrm{P}=0.05$ probability level. 
TABLE 5.-Marketable yields obtained from three banana cultivars grown without imigation during a 3-year period at Corozal Substation, Puerto Rico.

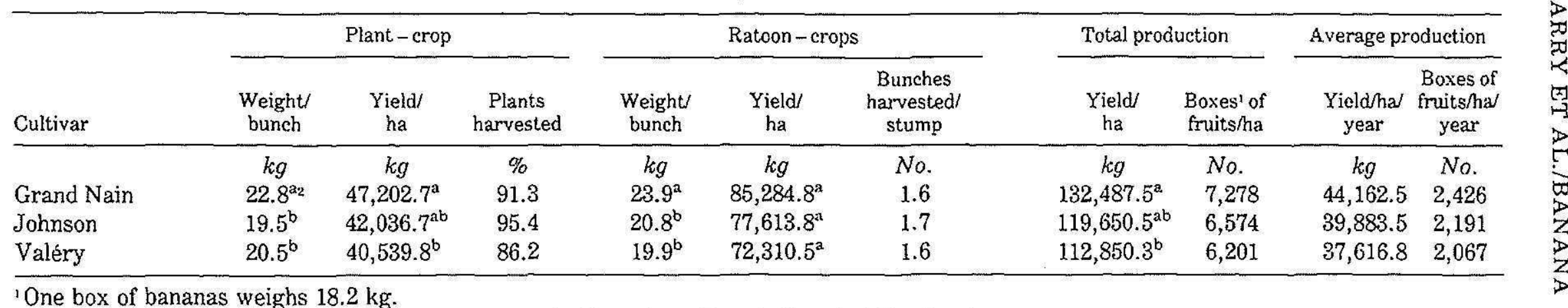

${ }^{2}$ Means followed by the same letters do not differ significantly at $\mathrm{P}=0.05$ probability level. 
TABLE 6.-Marketable yields oblained from four banana cultivars grown without irrigation during a 3-year period at the Gurabo Substation, Puerto Rico.

\begin{tabular}{|c|c|c|c|c|c|c|c|c|c|c|}
\hline \multirow[b]{2}{*}{ Cultivar } & \multicolumn{3}{|c|}{ Plant-crop } & \multicolumn{3}{|c|}{ Ratoon-crops } & \multicolumn{2}{|c|}{ Total production } & \multicolumn{2}{|c|}{ Average production } \\
\hline & $\begin{array}{l}\text { Weight } \\
\text { bunch }\end{array}$ & $\begin{array}{l}\text { Yield! } \\
\text { ha }\end{array}$ & $\begin{array}{c}\text { Plants } \\
\text { harvested }\end{array}$ & $\begin{array}{l}\text { Weight/ } \\
\text { bunch }\end{array}$ & $\begin{array}{c}\text { Yield } \\
\text { ha }\end{array}$ & $\begin{array}{l}\text { Bunches } \\
\text { harvested/ } \\
\text { stump }\end{array}$ & $\begin{array}{c}\text { Yield/ } \\
\text { ha }\end{array}$ & $\begin{array}{l}\text { Boxes' of } \\
\text { fruits/ha }\end{array}$ & $\begin{array}{l}\text { Yield/hal } \\
\text { year }\end{array}$ & $\begin{array}{c}\text { Boxes of } \\
\text { fruitsha } \\
\text { year }\end{array}$ \\
\hline & $k g$ & $\mathrm{~kg}$ & $\%$ & $k g$ & $\mathrm{~kg}$ & No. & $\lg$ & No. & $k g$ & No. \\
\hline Ziv & $17.0^{a_{2}}$ & $36,093.7^{\mathrm{a}}$ & 94.0 & $15.5^{\mathrm{a}}$ & $60,628.5^{a}$ & 1.7 & $96,722.2^{\mathrm{a}}$ & 5,314 & $32,240.7$ & 1,771 \\
\hline Grand Nain & $15.0^{\mathrm{b}}$ & $27,891.5^{b}$ & 79.0 & $14.1^{\mathrm{a}}$ & $56,922,2^{\mathrm{a}}$ & 1.8 & $84,813.7^{\mathrm{ab}}$ & 4,660 & $28,271.2$ & 1,553 \\
\hline Johnson & $14.4^{\mathrm{b}}$ & $30,714.3^{\mathrm{b}}$ & 94.5 & $15.2^{\mathrm{a}}$ & $53,705.5^{\mathrm{a}}$ & 1.6 & $84,419.8^{\mathrm{ab}}$ & 4,638 & $28,139.9$ & 1,546 \\
\hline Valéry & $12.8^{b}$ & $28,098.5^{6}$ & 97.5 & $14.0^{\mathrm{a}}$ & $55,055.7^{\mathrm{a}}$ & 1.7 & $83,154.2^{\mathrm{b}}$ & 4,569 & $27,718.1$ & 1,523 \\
\hline
\end{tabular}

One box of bananas weighs $18.2 \mathrm{~kg}$.

${ }^{2}$ Means followed by the same letters do not differ significantly at $\mathrm{P}=0.05$ probability level. 
persistently yielded the heaviest individual bunches, averaging $23.4 \mathrm{~kg}$ for all harvests.

At Gurabo, on a poorly-drained heavy Coloso clay soil, all cultivars performed at relatively substantial levels (table 6). Ziv was the highest producer with $96,722 \mathrm{~kg} / \mathrm{ha}$ (5,314 boxes) during the 3 -year period. Yield differences between Grand Nain and Johnson were not statistically significant.

In the Gurabo plant crop, Ziv was the best producer: $36,094 \mathrm{~kg} / \mathrm{ha}$ in a 14-month crop cycle (table 6). Although in successive ratoons this cultivar continued to rank first, yields were not significantly superior to the others. In ratoon crops, Grand Nain, Johnson and Valéry cultivars sustained an average $12 \%$ yield increase over the plant crop. However, total yields were low because only 1.6 to 1.8 bunches per stump were harvested during the final 22 months of the 3 -year study. Throughout the study the heaviest bunches were harvested from cultivar Ziv, averaging $16.3 \mathrm{~kg}$ (table 6).

Also, throughout the experiments Johnson showed a high degree of instability for plant height. After the plant crop was harvested some

TABLE 7.-Ratings oblained by ethylene-ripened banana samples subjected to sensorial evaluations, November 16 through December 27, 1982

\begin{tabular}{|c|c|c|c|c|}
\hline Cultivar & Appearance' & Flavor & Texture & $\begin{array}{c}\text { Overall } \\
\text { Acceptability }\end{array}$ \\
\hline \multicolumn{5}{|c|}{ November 16,1982} \\
\hline Johnson & $5.3^{\mathrm{a}_{2}}$ & $5.1^{\mathrm{a}}$ & $5.1^{\mathrm{a}}$ & $5.1^{\mathrm{a}}$ \\
\hline Valéry & $5.3^{\mathrm{a}}$ & $4.8^{\mathrm{ab}}$ & $4.9^{2}$ & $4.7^{2}$ \\
\hline Ziv & $5.2^{\mathrm{a}}$ & $4.3^{b}$ & $4.7^{\mathrm{a}}$ & $4.5^{2}$ \\
\hline Grand Nain & $5.0^{\mathrm{a}}$ & $4.9^{\mathrm{ab}}$ & $4.9^{\mathrm{a}}$ & $4.9^{\mathrm{a}}$ \\
\hline \multicolumn{5}{|c|}{ December 3, 1982} \\
\hline Grand Nain & $5.5^{\mathrm{a}}$ & $5.0^{\mathrm{a}}$ & $5.0^{\mathrm{a}}$ & $5.0^{\mathrm{a}}$ \\
\hline Valéry & $5.5^{\mathrm{a}}$ & $4.5^{\mathrm{a}}$ & $4.7^{\mathrm{a}}$ & $4.5^{\mathrm{a}}$ \\
\hline Johnson & $5.2^{\mathrm{a}}$ & $5.2^{\mathrm{a}}$ & $5.2^{\mathrm{a}}$ & $5.0^{\mathrm{a}}$ \\
\hline Ziv & $5.2^{\mathrm{a}}$ & $3.3^{b}$ & $3.5^{\mathrm{b}}$ & $3.5^{\mathrm{b}}$ \\
\hline \multicolumn{5}{|c|}{ December 28,1982} \\
\hline Grand Nain & $5.3^{2}$ & $4.8^{\mathrm{a}}$ & $4.6^{\mathrm{a}}$ & $5.2^{\mathrm{a}}$ \\
\hline Valéry & $5.1^{2}$ & $4.6^{\mathrm{a}}$ & $4.8^{\mathrm{a}}$ & $4.7^{\mathrm{ab}}$ \\
\hline Johnson & $5.0^{2}$ & $4.9^{2}$ & $4.4^{\mathrm{a}}$ & $5.2^{\mathrm{a}}$ \\
\hline Ziv & $4.1^{b}$ & $4.1^{a}$ & $3.9^{\mathrm{a}}$ & $3.8^{b}$ \\
\hline \multicolumn{5}{|c|}{ December 27,1982} \\
\hline Valéry & $5.6^{\mathrm{a}}$ & $4.8^{\mathrm{ab}}$ & $5.1^{\mathrm{a}}$ & $5.0^{\mathrm{a}}$ \\
\hline Johnson & $5.0^{a b}$ & $4.5^{b}$ & $4.9^{\mathrm{ab}}$ & $4.9^{a b}$ \\
\hline Grand Nain & $4.4^{\mathrm{bc}}$ & $5.3^{\mathrm{a}}$ & $5.1^{\mathrm{a}}$ & $5.0^{\mathrm{a}}$ \\
\hline $\mathrm{Ziv}$ & $3.9^{c}$ & $4.4^{\mathrm{b}}$ & $4.2^{b}$ & $3.9^{\mathrm{b}}$ \\
\hline
\end{tabular}

16-point scale, $6=$ like very much; $1=$ do not like.

${ }^{2}$ Means followed by the same letters do not differ significantly at $P=0.05$ probability level. 
ratoon suckers often developed into vigorous tall plants similar to the Giant Montecristo.

When properly ripened, none of the cultivars were affected by "finger drops."

\section{Sensorial evaluations of ripe bananas}

Eight ethylene-ripened banana samples were evaluated by a taste panel. At four evaluation dates (December 1, 7, 13 and 23, 1982), the taste panel did not detect appreciable differences among cultivars for fruit appearance (size, color, shape), flavor, texture (mouthfeel) and overall acceptability. Depending on the characteristic and sampling date, these attributes averaged 4.7 points in a grading scale of 1 to 6 .

However, significant differences were detected among cultivars for evaluations conducted November 16, December 3, 23, and 27, 1982 (table 7). Consistently, higher ratings were obtained by Grand Nain, Valéry and Johnson for fruit appearance, flavor, texture and overall acceptability. On the other hand, Ziv was often rated below 4 points, principally because of dull yellow fruits and off-flavors. These defects prevented the taste panel from reaching a concensus in their preference for these fruits.

\section{LITERATURE CITED}

1. Boncanto, A. A., 1969. Effects of reducing the number of hands in a bunch of Lacatan banana. Philipp. .I. Plant Ind., 32 (2-4): 234-51.

2. Calvo, J. and M. Soto, 1985. Effect of dehanding in banana fruit quality in the "Great Dwarf" cultivar, Musa AAA Cavendish. Proc. ACORBAT, 7th Meet, (Sept. 23-27), San José, Costa Rica. 311-15.

3. González-Ríos, P., 1931. El cultivo del banano en Puerto Rico. Rev. Agric, P. R. 26 (8-9): 58-71, 75-82.

4. Irizarry, $\mathrm{H}$. and J. Vicente-Chandler, 1984. Perspectivas para la producción de guineos para la exportación. Revista del Colegio de Agrónomos de P. R.(Núm. enero-marzo), 13 y 15 .

5. and R. Montalvo-Zapata, 1986. Conjunto tecnológico para la producción de plátanos y guineos. Pub]. 97, 2nda. ed., Esta. Exp. Agric., Univ. P. R.

6. Larmond, E., 1977. Laboratory methods for sensory evaluation of food. Publ. 1637, Res. Branch, Canada, Dep. Agric.

7. Osuna, P., 1947. El cultivo de plátanos y guineos. Rev. Agric. P. R. 38 (1): 61-3.

8. Pool, D. J., Evaluation of banana cultivars for fresh fruit market in Puerto Rico. Fruits 39 (2): 112-14.

9. Sánchez-Nieva, F., I. Hernández and C. Bueso de Viñas, 1969. Ripening of Montecristo bananas. J. Agric. Univ. P. R. 53 (4): 274-83.

10. — G. Colom-Covas, I. Hernández, C. Bueso de Viñas and R. Guadalupe, 1969. Studies on the production of Montecristo banana grown on the south coast of Puerto Rico. J. Agric. Univ. P. R. 53 (4): 284-306.

11.

R. Guadalupe, C. Bueso de Viñas and A. Torres, 1969. Studies

on the production of Montecristo banana grown in the Adjuntas region of Puerto Rico. J. Agric. Univ. P. R. 53 (4): 307-26.

12.

, C. Bueso de Viñas, R. Guadalupe and A. Torres, 1970. Effect of zone and climate on yield, quality and ripening characteristics of Montecristo bananas grown in Puerto Rico. J. Agric. Univ. P. R. 54 (2): 195-210. 